\title{
Mycotoxins Contamination Levels in Broiler Feeds and Aflatoxin Residues in Broiler Tissues
}

\author{
Anwaar M. El-Nabarawy ${ }^{1 *}$, Elshaimaa Ismael ${ }^{2}$, Khaled A. Shaaban ${ }^{1}$, Sawsan S. El Basuni ${ }^{3,}$ Mohamed M. Batikh ${ }^{4}$ \\ and Mohamed Shakal ${ }^{1}$ \\ ${ }^{1}$ Poultry Disease Department, Faculty of Veterinary Medicine, Cairo University, Egypt. \\ ${ }^{2}$ Department of Veterinary Hygiene and Management, Faculty of Veterinary Medicine, Cairo University, Egypt. \\ ${ }^{3}$ Avian and Rabbit Diseases Department- Faculty of Veterinary Medicine, Benha University, Egypt. \\ ${ }^{4}$ Poultry Disease Department, Animal Health Research Institute, Kafr El-sheikh Provisional Lab, Egypt. \\ *Corresponding author's E-mail: anwaar.elnabarawy@gmail.com; ORCID: 0000-0003-1618-6842
}

Received: 24 Feb. 2020

Accepted: 02 Apr. 2020

\begin{abstract}
The need for regulations to limit the concentration of mycotoxins in feed and food requires the availability of data on levels of contamination in different feedstuffs and estimation of the mycotoxin residues in animal meat. Therefore, this study was conducted to determine contamination levels with different mycotoxins in broiler feed and aflatoxin residues in broilers' muscle and liver. A total of 194 feed samples, including 148 compound feeds and 46 feed ingredients, were collected from feed manufacturing companies and broiler farms. Feed samples were analyzed for detecting aflatoxins, ochratoxins, zearalenone, and fumonisins using an official analytical method. Moreover, aflatoxin residues were estimated in 64 broiler's muscle and liver tissues. Obtained results revealed that $100 \%$ of compound broiler feed sampled from manufacturing companies were contaminated with aflatoxin and ochratoxin. Also, $96.4 \%$ and $92.8 \%$ of compound broiler feed sampled from broiler farms were contaminated with aflatoxin and ochratoxin, respectively. Furthermore, $30.6 \%$ and $91 \%$ of the feed samples were above the permissible levels of aflatoxin and ochratoxin. Aflatoxin residues were detected in all meat and liver samples with levels above the permissible limits. Large scale surveys for determination of different mycotoxins in poultry feed and mycotoxins residues in poultry products are of national and international importance.
\end{abstract}

Key words: Aflatoxin, Broiler feed, Fumonisin, Mycotoxin residue, Ochratoxins, Zearalenone.

\section{INTRODUCTION}

Mycotoxins are secondary metabolites produced by mycotoxigenic fungi infecting feed ingredients under field and storage conditions and they remain long after the death of the mold (Aravind et al., 2003). Moreover, the cooccurrence of mycotoxins in poultry feed is more prevalent than a single mycotoxin (Atalla et al., 2003; Kana et al., 2013; Kovalsky et al., 2016). Concomitant contamination by several mycotoxins may augment their toxic effects (Huff and Doerr, 1981; Chandrasekaran 1996; Pappas et al., 2014). Aflatoxin, ochratoxin A, zearalenone, T-2 toxin, vomitoxin, and fumonisin are the most significant mycotoxins affecting poultry species through naturally contaminated feeds and have serious toxic effects and probable synergistic properties (Njobeh et al., 2012). The combined effect of ochratoxin and aflatoxin at a dose of 23 and $16 \mathrm{ppb}$; respectively, resulted in depressed $\mathrm{T}$ and $\mathrm{B}$ lymphocytes activity, suppressed immunoglobulin and antibody production (El Nabarawy et al., 2016). Naturally contaminated broiler diet by aflatoxin, ochratoxin, and zearalenone at permissible levels resulted in a significant reduction in feed conversion rate, body weight and antibody titers to infectious bursal disease virus (El Nabarawy et al., 2020). Permissible limits of mycotoxins in poultry feed and feed ingredients are $20 \mathrm{ppb}$ for aflatoxins (FDA, 2000; van Egmond and Jonker, 2004a), $25 \mathrm{ng} / \mathrm{g}$ for ochratoxins (EC, 2006), 10 ppm for zearalenone (FDA, 2010) and $100 \mathrm{ppm}$ for fumonisin (FDA, 2001). Besides, zearalenone is receiving serious attention for control, since it is considered a mycotoxin indicator in addition to its synergistic action with other mycotoxins, but its regulation needs further attention (Park and Troxell, 2002).

The contaminated animal feed is the major cause of exposure to mycotoxins in animals and therefore ultimately in humans (Bryden, 2012). In the last few decades, the increase in the incidence of various types of cancers between various categories of people may be contributed to dietary factors, aflatoxins and agrochemical 
contaminated foods (Maiyoh and Tuei, 2019). In the same respect, van Egmont and Jonker (2004b) reported that dietary contamination of aflatoxins represents a major risk to public health and aflatoxins are known to have a strong hepatotoxic and carcinogenic effect. In general, the consumption of contaminated food induces neurotoxic, immunosuppressive, teratogenic, mutagenic and carcinogenic effects in humans (Fernandez et al., 2000). Mohd-Redzwan et al. (2013) reported on cumulative evidence from humans revealed a strong linkage occurs between aflatoxin and hepatic chronic carcinoma (HCC). Also, acute aflatoxicosis induced abdominal pain, vomiting, edema, and death. Moreover, aflatoxicosis outbreak was recorded four times in Kenya from 2004 to 2014, with mean 600 individuals were affected, and 211 deaths were estimated from this outbreak (Awuor et al., 2017). Hence, the European community and many other countries have determined $2 \mathrm{ng} / \mathrm{g}$ aflatoxin B1 (AFB1) and $4 \mathrm{ng} / \mathrm{g}$ total aflatoxin as maximum tolerance levels in human food products (Van Egmond and Jonker, 2004b; Wild and Gong, 2009). The accumulation of AFB1 residues in broiler meat and liver leads to the toxin carryover through the food chain. AFB1 residues may persist unchanged in the liver even when exposure levels are relatively low (Magnoli et al., 2002). The occurrence and incidence of aflatoxins, ochratoxins, and zearalenone in chicken meat are alarming and urged the need for continuous monitoring for these toxins in chicken meat and eggs (Iqbal et al., 2014).

There are very limited data on the epidemiological status of mycotoxins in broilers feed and meat in Egypt. Therefore, the objective of this work was to study the situation of the contamination levels of aflatoxin, ochratoxin, zearalenone, and fumonisins in broilers feed and the level of aflatoxin residues in broiler tissues.

\section{MATERIALS AND METHODS}

Sampling, extraction and determination of mycotoxins in broilers feed and feed ingredients Sampling of broiler feed

A surveillance study was carried out on different mycotoxins contamination levels in broilers feed in 2014 and 2018. A total of 194 broiler feed samples including 148 compound broilers feeds and 46 feed ingredients were collected from feed manufacturing companies $(n=37)$ and broilers farms $(n=111)$ for mycotoxins detection and determination. The samples were collected by a representative method according to the recommendation of the FAO for detection and determination of aflatoxins, ochratoxin A, zearalenone, and fumonisin mycotoxins.

\section{Requirements and consumable materials}

A) Mycotoxins columns: Aflatest, ochratest, zearalatest, and fumonitest, each type of toxin has its specific column which is consumed for one sample.

B) Chemicals and reagents: Methanol, HPLC grade (4X4L), Distilled deionized water, and Nonionized sodium chloride (salt, $\mathrm{NaCl}$ ), Afla test developer, Phosphate buffered saline (PBS) Lot: 17021PBS, Ochratest eluting solution Lot: 17061E, 0.1 tween PBS Lot: 17011G2, Zearalatest developer Lot: 102594-4, and fumonisin A and B developer, were utilized in the analysis.

C) Mycotoxins calibration standards: One vial; each of 3 levels, for aflatest, ochratest, zearalatest, and fumonitest calibration.

D) Fluorometer series 4: Fluorometer series 4 provides an accurate and sensitive measurement for aflatoxin, ochratoxin, zearalenone, and fumonisins mycotoxins.

\section{Extraction of mycotoxins}

Mycotoxins were extracted from representative samples of broilers feed where $50 \mathrm{~g}$ of each ground sample was mixed with $5 \mathrm{~g}$ sodium chloride analar and $100 \mathrm{ml}$ methanol: water (80: 20 by volume) solution. The mixture was blended at high speed for 1 minute and then the extract was filtered through fluted filter paper. For aflatoxin; $10 \mathrm{ml}$ filtered extract was mixed with $40 \mathrm{ml}$ distilled water, then filtered through a glass microfiber filter (VICAM, 1999). For ochratoxin; 10ml filtered extract was mixed with $40 \mathrm{ml}$ phosphate-buffered saline (PBS), then filtered through a $1.5 \mu \mathrm{m}$ glass microfiber filter (VICAM, 2008). For zearalenone, $1 \mathrm{ml}$ filtered extract was mixed with $49 \mathrm{ml}$ distilled water and then filtered through microfiber filter (VICAM, 2013). For fumonisin, $10 \mathrm{ml}$ filtered extract was mixed with $40 \mathrm{ml}$ of $0.1 \%$ Tween-20/2.5\% PEG/PBS wash buffer, then filtered through a $1.5 \mu \mathrm{m}$ microfiber filter (VICAM, 2015).

For aflatoxins, $10 \mathrm{ml}$ of the filtered diluted extract was passed through the affinity column at a rate of about 1 $\mathrm{drop} / \mathrm{second}(10 \mathrm{ml}=1.0 \mathrm{~g}$ sample equivalent $)$. Then, the column was washed with $10 \mathrm{ml}$ distilled water at a rate of 1-2 drops/second. The affinity column was then eluted with $1.0 \mathrm{ml}$ HPLC grade methanol at a rate of 1 drop/second, and the elute was collected in a glass cuvette, to where $1 \mathrm{ml}$ of freshly made test developer solution was added (VICAM, 1999). For ochratoxin, 10ml of the filtered diluted extract was passed through the affinity column, then the column was washed with $10 \mathrm{ml} 0.1 \%$ 
Tween 20/PBS followed by $5 \mathrm{ml}$ purified water, and $1.5 \mathrm{ml}$ OchraTest $^{\mathrm{TM}}$ Elution Solution was used to elute the column (VICAM, 2008). For zearalenone, $1 \mathrm{ml}$ of the filtered diluted extract was passed through the affinity column, then the column was washed with $10 \mathrm{ml}$ distilled water, and eluted with $1 \mathrm{ml}$ HPLC grade methanol, on which a $1 \mathrm{ml}$ ZearalaTest ${ }^{\mathrm{TM}}$ Developer was added (VICAM, 2013). For fumonisin, $5 \mathrm{ml}$ of the filtered diluted extract was passed through the affinity column, then the column was super-washed with $5 \mathrm{ml}$ of $0.1 \%$ Tween 20/2.5\% PEG/PBS followed by $5 \mathrm{ml}$ of PBS, and $1 \mathrm{ml}$ HPLC grade methanol was used to elute the column, and a $1 \mathrm{ml}$ mixture of Developers A and B was added (VICAM, 2015).

\section{Standardization of Fluorometer series 4}

Mycotoxin calibration standards (1 vial each of 3 levels). For aflaTest, calibration settings are adjusted to -1 , 27 , and $13 \pm 2$, with detection range $0-100 \mathrm{ppb}$, and limit of detection 1ppb (VICAM, 1999). For Ochratest, calibration settings are adjusted to $-1.3,30$, and $14 \pm 2$, with detection range $0-100 \mathrm{ppb}$, and limit of detection $2 \mathrm{ppb}$ (VICAM, 2008). For ZearalaTest, calibration settings are adjusted to $16,-2$, and $8 \pm 2$, with detection range $2-100$ ppm, and limit of detection 2ppm (VICAM, 2013). For FumoniTest, calibration settings are adjusted to $-0.50,12$, and $5.8 \pm 0.3$, with detection range $0-10 \mathrm{ppm}$, and limit of detection 0.25ppm for corn (VICAM, 2015).

\section{Determination of mycotoxins in broilers feed}

Fluorometer series 4 provides accurate and sensitive measurement of mycotoxins. AflaTest ${ }^{\circledR}$ WB SR, OchraTest $^{\mathrm{TM}}$, ZearalaTest ${ }^{\mathrm{TM}}$, and FumoniTest ${ }^{\mathrm{TM}}$ have been used for quantitative measurement of aflatoxins, ochratoxin A, zearalenone, and fumonisins in broilers feed and feed ingredients. These test kits are based on immunoaffinity chromatography. The fluorescence of the mycotoxin in the elution solution can then be measured in a fluorometer series 4 . Quality assurance and validation of Series-4 Fluorometer procedures were validated by the AOAC Research Institute under the Performance Tested Program to detect and determine mycotoxins, and were licensed under certification mark no. 940801.

Sampling, extraction and ELISA screening of total aflatoxin residues in the muscles and liver of broiler chickens

\section{Sampling of broilers liver and meat}

Upon obtaining the approval of the Institutional Animal Care and Use Committee (IACUC) on the Animal Use Protocol (AUP) (VetCU10102019093); 64 broilers' muscles and liver were collected from markets located in different governorates (1, 2 and 3), to determine aflatoxin residues.

\section{Extraction of aflatoxin residues}

The aflatoxin residues were extracted from Liver and muscles where $20 \mathrm{~g}$ of each ground sample was added to $100 \mathrm{ml}$ of the extraction solvent $(70 \%$ methanol), in which the ratio of sample to extraction solvent is 1:5 (w/v). After blending for $2 \mathrm{~min}, 5-10 \mathrm{ml}$ of the extract was filtered through a Whatman filter paper (Kensler et al., 2003; Williams et al., 2004; Klich, 2007).

ELISA screening of total aflatoxin residues in the muscles and liver of broiler chickens

The concentration of total aflatoxin residues in the tissue of muscles and liver of broiler chickens was determined by a solid-phase competitive inhibition enzyme-linked immune-assay (ELISA), using HELICA ${ }^{\circledR}$ Low Matrix Total Aflatoxin Assay Kits (HELICA Biosystems, Inc. Santa Ana, CA). The extracted filtrate and the aflatoxin- horse-radish peroxidase (HRP) enzyme conjugate were mixed and added to the antibody-coated microwell. After a step of 5 washes, an enzyme-substrate was added, and the blue color was developed. This was followed by the addition of a stop solution. Absorbances were read at $450 \mathrm{~nm}$ by a computerized microplate reader and the optical densities (OD) of the samples were compared to the ODs of the kit standards and a result was determined by interpolation from the standard curve and the total concentration expressed in ng/g (Kensler et al., 2003; Williams et al., 2004; Klich, 2007).

\section{Statistical analysis}

Descriptive analysis of mycotoxin levels was performed using PASW Statistics software, version 18.0 (SPSS Inc., Chicago, IL, USA).

\section{RESULTS AND DISCUSSION}

Feedstuffs contamination by mycotoxins represents a great threat to broilers industry and public health. As shown in Table 1 and Figures 1 and 5, rates of mycotoxins in compound broiler feed in 2014 and 2018 revealed that all 37 analyzed samples were positive to aflatoxin and ochratoxin and their levels ranged from 1 to $55 \mathrm{ppb}$ (mean $=14.33 \mathrm{ppb}$ in 2014 and $20.36 \mathrm{ppb}$ in 2018) and 1.8 to 71 ppb (mean $=27.85 \mathrm{ppb}$ in 2014 and $3.12 \mathrm{ppb}$ in 2018), respectively. In addition, zearalenone and fumonisins were detected in $21(56.8 \%)$ and $6(16.2 \%)$ of the examined samples, respectively, with levels range of 0.48 to $10 \mathrm{ppm}$ (mean $=1.06 \mathrm{ppm}$ in $2014 ; 3.80 \mathrm{ppm}$ in 2018) and 1.2 to $12 \mathrm{ppm}$ (mean $=7.17 \mathrm{ppm}$ ), respectively. 
Table 1. Levels of mycotoxins contamination in broiler feed sampled from manufacturing companies in 2014 and 2018

\begin{tabular}{|c|c|c|c|c|c|c|c|c|c|c|c|}
\hline Year & $\begin{array}{l}\text { No. of } \\
\text { sample }\end{array}$ & $\begin{array}{c}\text { Aflatoxin } \\
\text { ppb }\end{array}$ & $\begin{array}{c}\text { Ochratoxin } \\
\text { ppb }\end{array}$ & $\begin{array}{c}\text { Zearalenone } \\
\text { ppm }\end{array}$ & $\begin{array}{c}\text { Fumonisin } \\
\text { ppm }\end{array}$ & Year & $\begin{array}{l}\text { No. of } \\
\text { sample }\end{array}$ & $\begin{array}{c}\text { Aflatoxin } \\
\text { ppb }\end{array}$ & $\begin{array}{c}\text { Ochratoxin } \\
\text { ppb }\end{array}$ & $\begin{array}{c}\text { Zearalenone } \\
\text { ppm }\end{array}$ & $\begin{array}{c}\text { Fumonisin } \\
\text { ppm }\end{array}$ \\
\hline \multirow{21}{*}{2014} & 1 & 13 & 19 & - & 8.3 & \multirow{21}{*}{2018} & 1 & 19 & 2.9 & 3.9 & - \\
\hline & 2 & 32 & 66 & 1.2 & 12 & & 2 & 52 & 2.3 & 5.1 & - \\
\hline & 3 & 27 & 71 & 1.2 & - & & 3 & 41 & 1.8 & 5.1 & - \\
\hline & 4 & 9 & 8.9 & - & - & & 4 & 51 & 1.9 & 7.2 & - \\
\hline & 5 & 9 & 18 & - & - & & 5 & 55 & 2.8 & 10 & - \\
\hline & 6 & 6 & 29 & - & 1.2 & & 6 & 16 & 2.3 & 8.6 & - \\
\hline & 7 & 12 & 3.3 & 0.79 & - & & 7 & 27 & 2.7 & 8.2 & - \\
\hline & 8 & 8 & 43 & - & - & & 8 & 1 & 2.2 & 0.62 & - \\
\hline & 9 & 12 & 12 & - & - & & 9 & 3 & 22 & 0.52 & - \\
\hline & 10 & 13 & 7.5 & - & - & & 10 & 2 & 2.5 & 0.48 & - \\
\hline & 11 & 17 & 17 & - & - & & 11 & 4 & 3 & 1 & - \\
\hline & 12 & 15 & 20 & - & - & & 12 & 2 & 6 & 1 & - \\
\hline & 13 & 13 & 19 & - & - & & 13 & 2 & 4 & 1 & - \\
\hline & 14 & 32 & 66 & 1.2 & 8.3 & & 14 & 4 & 4 & 0.59 & - \\
\hline & 15 & 27 & 71 & 1.2 & 12 & & 15 & 11 & 3.9 & 4.2 & - \\
\hline & 16 & 9 & 8.9 & - & - & & 16 & 23 & 17 & - & - \\
\hline & 17 & 9 & 18 & - & - & & & & & & \\
\hline & 18 & 6 & 29 & - & - & & & & & & \\
\hline & 19 & 12 & 3.3 & 0.79 & 1.2 & & & & & & \\
\hline & 20 & 8 & 43 & - & - & & & & & & \\
\hline & 21 & 12 & 12 & - & - & & & & & & \\
\hline
\end{tabular}

- Not analyzed.

Table 2. Levels of mycotoxins contamination in broiler feed sampled from broiler farms in 2014.

\begin{tabular}{|c|c|c|c|c|c|c|c|c|c|}
\hline $\begin{array}{l}\text { Sample } \\
\text { No. }\end{array}$ & $\begin{array}{c}\text { Aflatoxin } \\
\text { ppb }\end{array}$ & $\begin{array}{c}\text { Ochratoxin } \\
\text { ppb }\end{array}$ & $\begin{array}{c}\text { Zearalenone } \\
\text { ppm }\end{array}$ & $\begin{array}{c}\text { Fumonisin } \\
\text { ppm }\end{array}$ & $\begin{array}{l}\text { Sample } \\
\text { No. }\end{array}$ & $\begin{array}{c}\text { Aflatoxin } \\
\text { ppb }\end{array}$ & $\begin{array}{c}\text { Ochratoxin } \\
\text { ppb }\end{array}$ & $\begin{array}{c}\text { Zearalenone } \\
\text { ppm }\end{array}$ & $\begin{array}{c}\text { Fumonisin } \\
\text { ppm }\end{array}$ \\
\hline 1 & 14 & 71 & 1.3 & 8.5 & 31 & 12 & 56 & - & - \\
\hline 2 & 85 & 28 & 8.9 & - & 32 & 11 & 54 & - & - \\
\hline 3 & 22 & 16 & 9.7 & - & 33 & 13 & 7.5 & 3.4 & 3.5 \\
\hline 4 & 18 & 15 & 1.6 & 14 & 34 & 17 & 17 & - & - \\
\hline 5 & 25 & 14 & 1.6 & 5.7 & 35 & 15 & 20 & - & - \\
\hline 6 & 9 & 8.6 & - & - & 36 & 6 & - & - & - \\
\hline 7 & 9 & 18 & - & - & 37 & 12 & 12 & - & - \\
\hline 8 & 12 & 0 & 1.1 & 6.1 & 38 & 3 & 11 & - & - \\
\hline 9 & 12 & 26 & 1.4 & 3.6 & 39 & 4 & 27 & - & - \\
\hline 10 & 13 & 44 & 0.98 & 5.2 & 40 & 13 & 13 & - & - \\
\hline 11 & 30 & 28 & 2.4 & - & 41 & 20 & 62 & - & - \\
\hline 12 & 2 & 12 & 2.3 & 3.8 & 42 & 10 & 57 & - & - \\
\hline 13 & 8 & 13 & - & - & 43 & 17 & 56 & - & - \\
\hline 14 & 14 & 17 & 1 & 4.1 & 44 & 12 & 56 & - & - \\
\hline 15 & 14 & 12 & 1.1 & - & 45 & 11 & 54 & 3.4 & 1.3 \\
\hline 16 & 1 & 16 & 1.1 & 5 & 46 & 15 & 20 & - & - \\
\hline 17 & 29 & 15 & 0.96 & - & 47 & 13 & 19 & - & - \\
\hline 18 & 0 & 21 & 1.3 & 5.6 & 48 & 13 & 7.5 & - & - \\
\hline 19 & 12 & - & - & - & 49 & 17 & 17 & - & - \\
\hline 20 & 17 & 22 & 1.4 & 19 & 50 & 9 & 8.9 & - & - \\
\hline 21 & 93 & 3 & - & - & 51 & 9 & 18 & - & - \\
\hline 22 & 8 & 24 & - & - & 52 & 32 & 66 & - & - \\
\hline 23 & 6 & - & - & - & 53 & 27 & 71 & - & - \\
\hline 24 & 12 & 12 & - & - & 54 & 10 & 57 & - & - \\
\hline 25 & 3 & 11 & - & - & 55 & 17 & 56 & - & - \\
\hline 26 & 4 & 27 & - & - & 56 & 12 & 56 & - & - \\
\hline 27 & 13 & 13 & - & - & 57 & 26 & 62 & - & - \\
\hline 28 & 20 & 62 & - & - & 58 & 3 & 11 & - & - \\
\hline 29 & 10 & 57 & - & - & 59 & 4 & 27 & - & - \\
\hline 30 & 17 & 56 & - & - & 60 & 12 & 3.3 & 0.79 & 1.2 \\
\hline
\end{tabular}


Table 3. Levels of mycotoxins contamination in broiler feed sampled from broiler farms in 2018.

\begin{tabular}{|c|c|c|c|c|c|c|c|c|c|}
\hline $\begin{array}{c}\text { Sample } \\
\text { No. }\end{array}$ & $\begin{array}{c}\text { Aflatoxin } \\
\text { ppb }\end{array}$ & $\begin{array}{c}\text { Ochratoxin } \\
\text { ppb }\end{array}$ & $\begin{array}{c}\text { Zearalenone } \\
\text { ppm }\end{array}$ & $\begin{array}{c}\text { Fumonisin } \\
\text { ppm }\end{array}$ & $\begin{array}{l}\text { Sample } \\
\text { No. }\end{array}$ & $\begin{array}{c}\text { Aflatoxin } \\
\text { ppb }\end{array}$ & $\begin{array}{c}\text { Ochratoxin } \\
\text { ppb }\end{array}$ & $\begin{array}{c}\text { Zearalenone } \\
\text { ppm }\end{array}$ & $\begin{array}{c}\text { Fumonisin } \\
\text { ppm }\end{array}$ \\
\hline 1 & 14 & 71 & 1.2 & 8.5 & 27 & 20 & 12 & 2.3 & 3.8 \\
\hline 2 & 9 & 8.6 & 0 & 0 & 28 & 0 & 0 & 13 & 0 \\
\hline 3 & 9 & 18 & 0 & 0 & 29 & 14 & 17 & 1 & 4.1 \\
\hline 4 & 0 & 21 & 1.2 & 5.6 & 30 & 14 & 12 & 1.1 & - \\
\hline 5 & 17 & 12 & 1.4 & 1.9 & 31 & 1 & 16 & 1.1 & - \\
\hline 6 & 25 & 14 & 0 & 0 & 32 & 29 & 15 & 0.96 & 5 \\
\hline 7 & 5 & 22 & 0 & 0 & 33 & 36 & 46 & 8.1 & 0 \\
\hline 8 & 17 & 12 & 1.4 & 1.9 & 34 & 34 & & 6.2 & 0 \\
\hline 9 & 33 & 18 & 0 & 0 & 35 & 19 & 1.7 & 7.8 & 0 \\
\hline 10 & 8 & 24 & 0 & 0 & 36 & 35 & 3.8 & 8.4 & 0 \\
\hline 11 & 18 & 15 & 1.6 & 14 & 37 & 43 & 2.1 & 7.9 & 0 \\
\hline 12 & 15 & 15 & 70 & 0 & 38 & 2 & 6 & 2 & 0 \\
\hline 13 & 10 & 10 & 40 & 0 & 39 & 25 & 30 & 1.5 & 0 \\
\hline 14 & 13 & 10 & 30 & 0 & 40 & 30 & 55 & 30 & 0 \\
\hline 15 & 25 & 15 & 20 & 0 & 41 & 50 & 40 & 0 & 0 \\
\hline 16 & 0 & 11 & 20 & 0 & 42 & 60 & 15 & 0 & 0 \\
\hline 17 & 0 & 10 & 0 & 0 & 43 & 100 & 30 & 0 & 0 \\
\hline 18 & 12 & 26 & 1.4 & 3.6 & 44 & 40 & 90 & 0 & 0 \\
\hline 19 & 22 & 16 & 3.7 & 0 & 45 & 60 & 50 & 0 & 0 \\
\hline 20 & 10 & 51 & 2.4 & 4.9 & 46 & 140 & 30 & 0 & 0 \\
\hline 21 & 10 & 57 & 0 & - & 47 & 55 & 30 & 0 & 0 \\
\hline 22 & 17 & 24 & 0 & 0 & 48 & 560 & 40 & 0 & 0 \\
\hline 23 & 35 & 22 & 8.9 & 0 & 49 & 40 & 20 & 0 & 0 \\
\hline 24 & 12 & 0 & 1.1 & 6.1 & 50 & 30 & 0 & 0 & 0 \\
\hline 25 & 13 & 44 & 0.98 & 5.2 & 51 & 60 & 0 & 0 & 0 \\
\hline 26 & 30 & 28 & 2.4 & - & & & & & \\
\hline
\end{tabular}

Table 4. Levels of mycotoxins contamination in feed ingredients

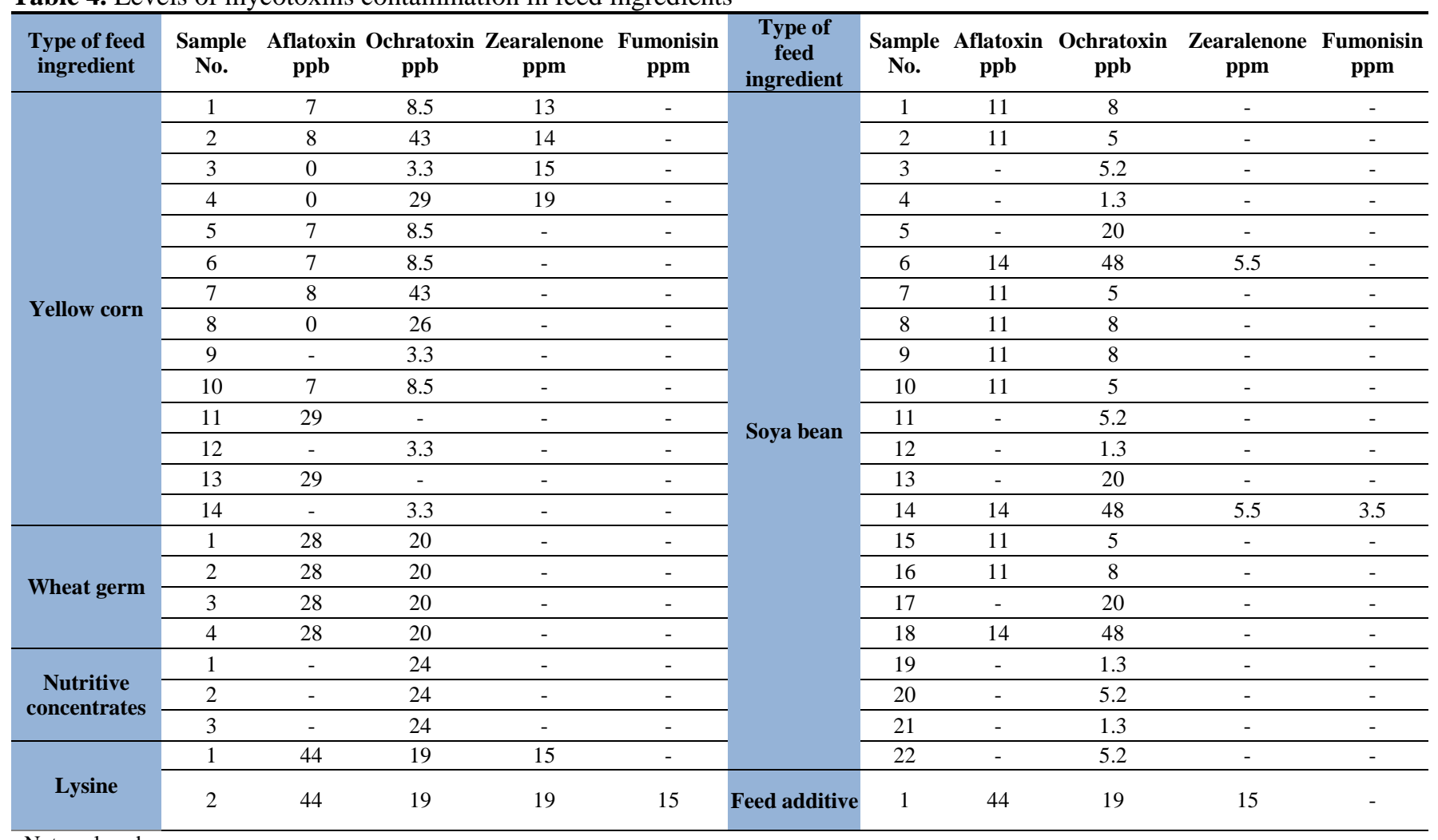


Table 5. Mean level of total aflatoxin residues in liver and muscle samples collected from commercial broiler chickens from different provinces of Egypt

\begin{tabular}{lcccccc}
\hline \multirow{2}{*}{ Province } & \multicolumn{6}{c}{ Total aflatoxin residues (ng/g) in tissue samples (n) } \\
\cline { 2 - 7 } & \multicolumn{2}{c}{ Breast (15) } & \multicolumn{2}{c}{ Thigh (28) } & \multicolumn{2}{c}{ Liver (21) } \\
\cline { 2 - 7 } 1 & Mean \pm SE & Range & Mean \pm SE & Range & Mean \pm SE & Range \\
2 & $20.30 \pm 2.80$ & $13.15-30.00$ & $12.90 \pm 4.90$ & $0.20-27.10$ & $22.30 \pm 4.40$ & $11.30-34.90$ \\
3 & $17.00 \pm 0.90$ & $16.05-17.85$ & $37.18 \pm 4.22$ & $13.15-69.40$ & $33.66 \pm 3.42$ & $6.80-4.20$ \\
Total & $20.30 \pm 1.10$ & $17.20-23.60$ & $19.20 \pm 1.40$ & $13.35-24.80$ & $17.70 \pm 2.70$ & $7.10-28.70$ \\
\hline
\end{tabular}

SE: Standard error. n: number

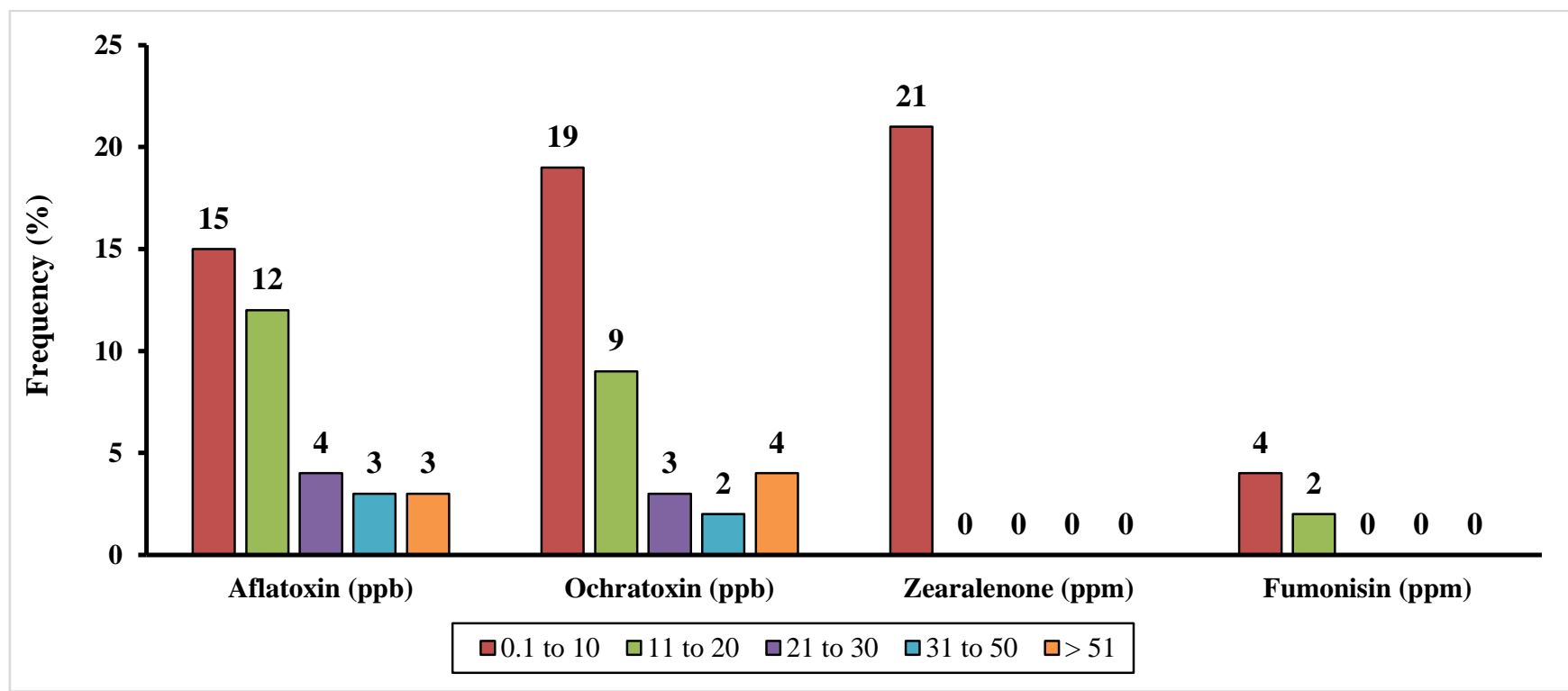

Figure 1. Mycotoxins contamination levels in compound broilers feed sampled from feed manufacturing companies, Egypt

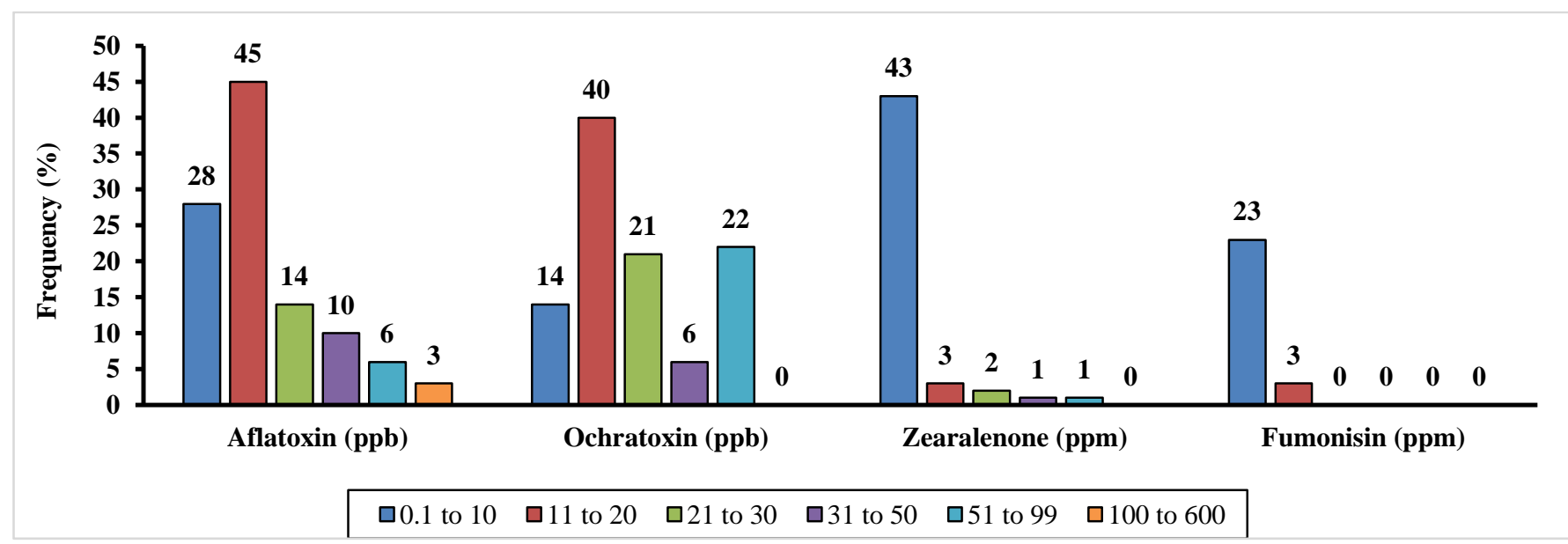

Figure 2. Mycotoxins contamination levels in compound broilers feed sampled from broiler farms, Egypt 


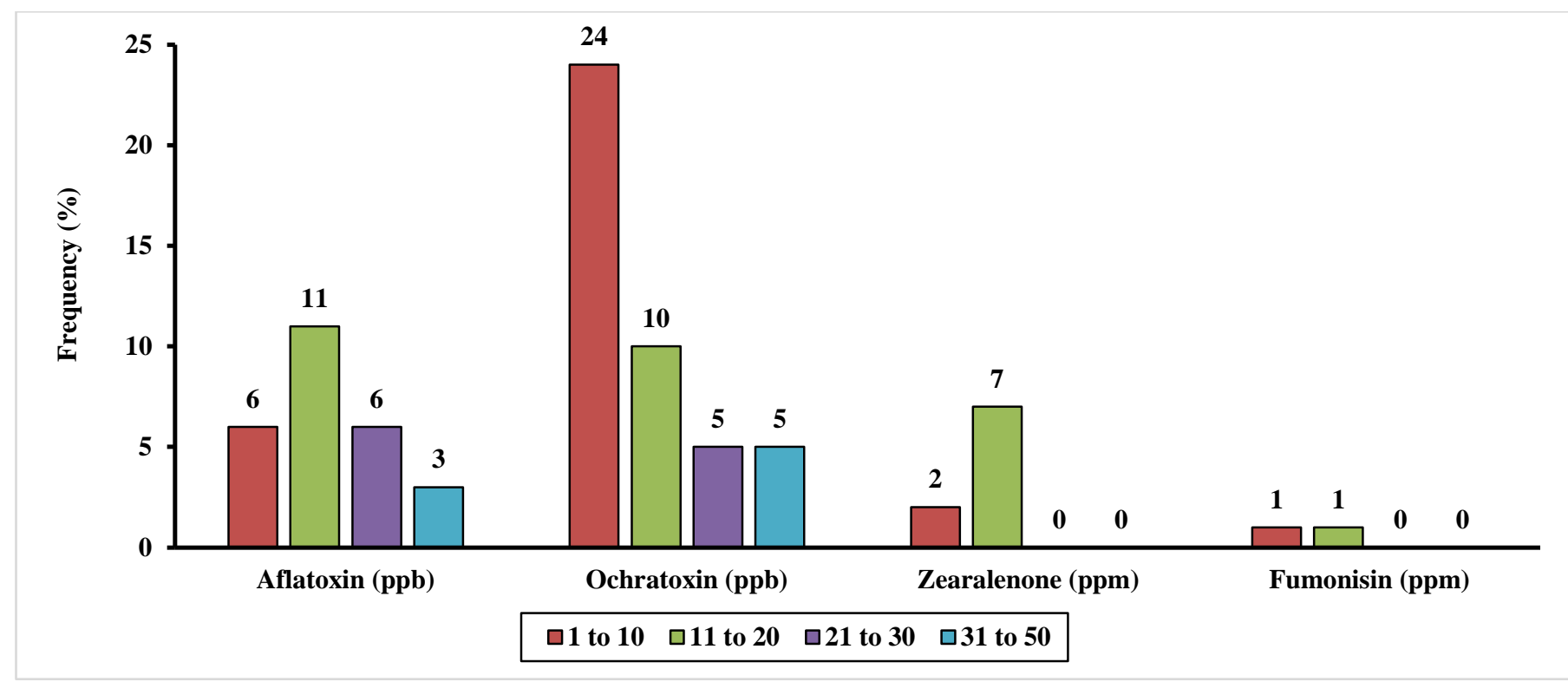

Figure 3. Mycotoxins contamination levels in feed ingredients
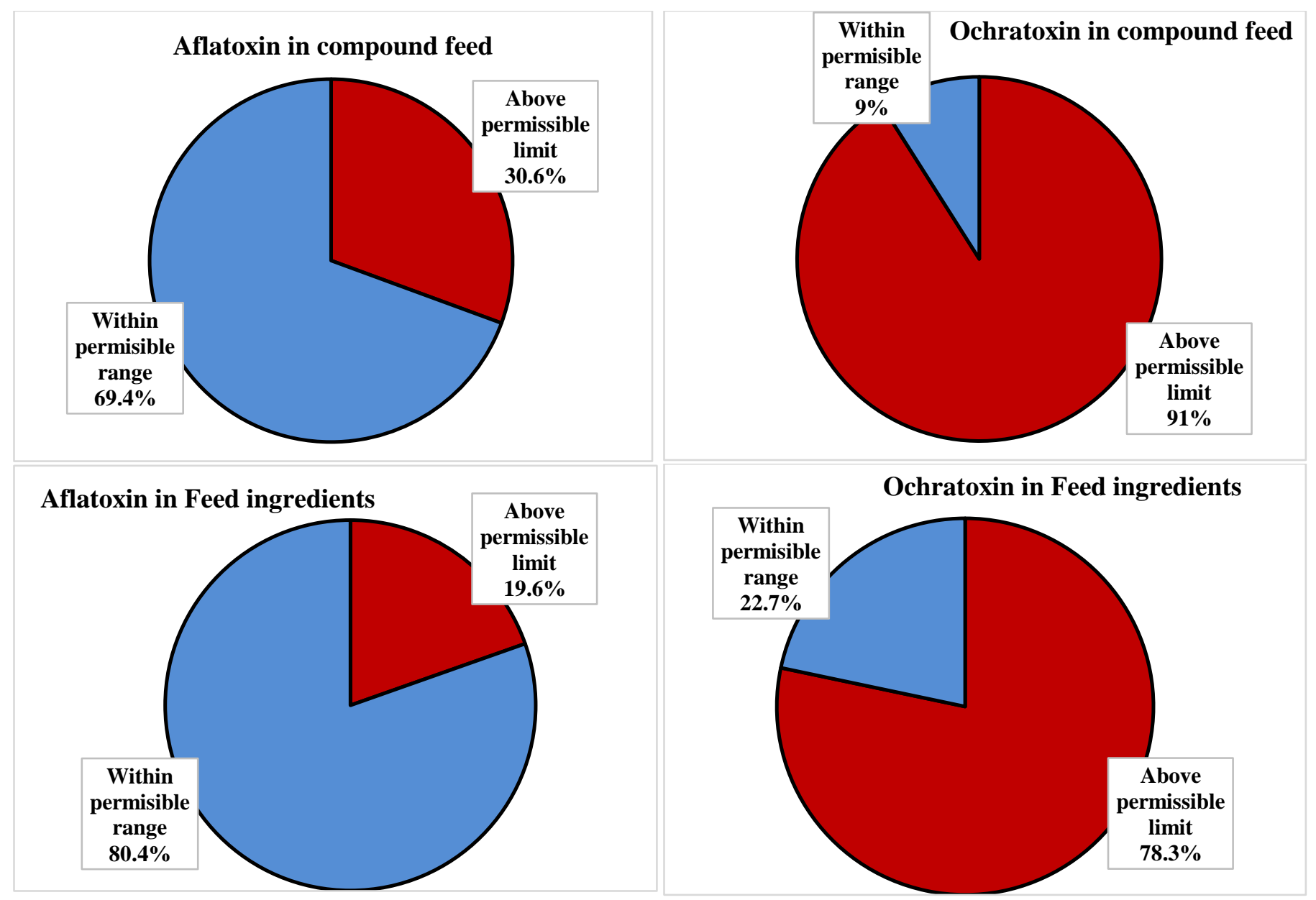

Figure 4. Percentage of aflatoxin and ochratoxin contamination exceeding the permissible limits (20 and 5 ppb; respectively according to FDA, 2000 and EC, 2006) in compound broilers feed and feed ingredients samples, Egypt. 


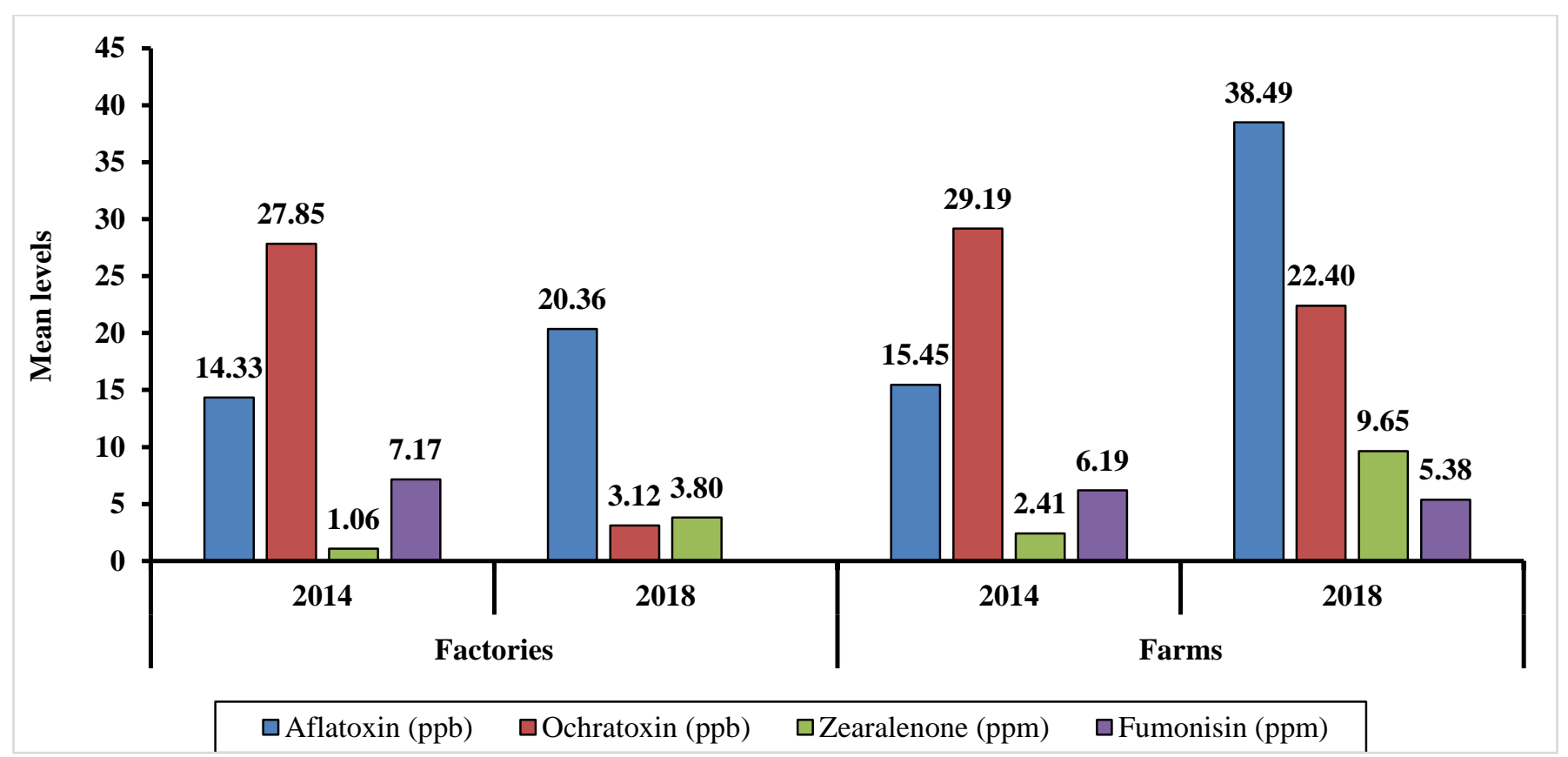

Figure 5. Mean levels of mycotoxins contamination in compound broilers feed in 2014 and 2018, Egypt

As illustrated in Tables 2 and 3 and Figures 2 and 5, rates of mycotoxins in compound broiler feed in 2014 and 2018 revealed that $96.4 \%$ and $92.8 \%$ of totally analyzed samples were positive to aflatoxin and ochratoxin with levels ranged from 1 to $560 \mathrm{ppb}$ (mean $=15.45 \mathrm{ppb}$ in 2014; $38.49 \mathrm{ppb}$ in 2018) and 1.7 to $90 \mathrm{ppb}$ (mean $=29.19$ ppb in 2014; $22.40 \mathrm{ppb}$ in 2018), respectively. Also, zearalenone and fumonisins were detected at a rate of $45.5 \%$ and $23.4 \%$, respectively, with levels range of 0.79 to $70 \mathrm{ppm}$ (mean $=2.41 \mathrm{ppm}$ in $2014 ; 9.65 \mathrm{ppm}$ in 2018) and 1.2 to $19 \mathrm{ppm}$ (mean= $6.19 \mathrm{ppm}$ in $2014 ; 5.38 \mathrm{ppm}$ in 2018), respectively. Table 4 and Figures 3 and 5 revealed that aflatoxin and ochratoxin in different types of feed ingredients were detected with rates $54.5 \%$ and $95.5 \%$, respectively and their levels ranged from 7 to 44 and 1.3 to $48 \mathrm{ppb}$, respectively. In addition, the prevalence of zearalenone and fumonisin was $20.5 \%$ and $4.5 \%$ in the analyzed samples with a range of 5.5 to 19 and 3.5 to 15 ppm, respectively. The obtained results revealed that the contamination levels of aflatoxins and ochratoxins were above the permissible values ( 20 and $5 \mathrm{ppb}$, respectively) in compound broilers feed at $30.6 \%$ and $91 \%$ and in feed ingredients at $19.6 \%$ and $78.3 \%$, respectively (Tables $1-4$, and figure 4).

\section{The FDA restricts levels of aflatoxin in food}

and animal feeds to $20 \mathrm{ppb}$ and the EU limits levels of aflatoxin to $15 \mathrm{ppb}$ (Yang et al., 2020). The reported levels of aflatoxins in poultry feed and their ingredients are parallel to those previously reported in Egypt and other countries. In a previous study, from 87-broiler feed samples collected from a poultry feed production unit in Kuwait, aflatoxin was detected in broiler starter at 0.48 ppb level (range 0 to $3.26 \mathrm{ppb}$ ), and in broiler finisher at $0.39 \mathrm{ppb}$ level (range 0 to $1.05 \mathrm{ppb}$ ) (Beg et al., 2006). Moreover, in Kuwait, aflatoxins were detected in $63.9 \%$ of poultry feed; with range 6 to $201 \mathrm{ppb}$ for AFB1, and 8 to 335 ppb for aflatoxin B2 (Natour et al., 1983). In Egypt, $80 \%$ of the sampled maize contained aflatoxins at $480 \mathrm{ppb}$ level (Mahmoud, 1993). In Turkey, $71 \%$ of layer feed samples showed an aflatoxin level of less than $5 \mathrm{ppb}$, and only 2 samples exceeded acceptable levels (20-ppb) (Nizamlýolu and Oguz, 2003). In Bangladesh, poultry feed showed aflatoxin levels ranged from 7 to $160 \mathrm{ppb}$ (Dawlatana et al., 2002), while 216- feed ingredients from a poultry feed factory in India, showed contamination with aflatoxin in $60 \%$ of the mixed feed samples, with range 10 to 1500 ppb (Thirumala-Devi et al., 2002). In Nigeria, analysis of 102 samples of poultry feed and feed ingredients from poultry farms showed AFB 1 in $83 \%$ of feed samples (range, 0.5-760 ppb; mean, $74 \mathrm{ppb)}$ (Akinmusire et al., 2019). In South Africa, aflatoxins reported the lowest prevalence (30\% of samples) with levels ranged between 0.2 to $71.8 \mathrm{ppb}$ (mean: $9.0 \mathrm{ppb}$ ) (Njobeh et al., 2012). In Cameroon, Abia et al. (2013) analyzed 20 feed samples pools collected from different 
poultry farms and reported the rate of contamination with aflatoxins of $75-95 \%$. In Argentina, Greco et al. (2014) detected aflatoxins in $90 \%$ of poultry feed samples (median $2.685 \mathrm{ppb}$ ).

Since ochratoxin A was discovered in 1965, it has been ubiquitous as a natural contaminant of moldy food and feed. The multiple toxic effects of ochratoxin A are a real threat to human beings and animal health. Humans exposed to ochratoxin A can develop a range of chronic disorders and plays the main role in the pathogenesis of some renal diseases including Balkan endemic nephropathy, kidney tumors occurring in certain endemic regions of the Balkan Peninsula, and chronic interstitial nephropathy occurring in Northern African countries and likely in other parts of the world (Malir et al., 2016). Worthwhile, the EU has set a maximum limit of $5 \mathrm{ppb}$ for cereal products (Yang et al., 2020). In our study, the vast contamination of the poultry feed and feed ingredients with ochratoxin-A agrees with several previous reports. In Kuwait, broiler feed showed ochratoxin levels ranged from 4.6 to $9.6 \mathrm{ppb}$ (Beg et al., 2006). In Argentina, ochratoxin was found in $38 \%$ of the poultry feed samples with levels ranged from 25 to $30 \mathrm{ppb}$ (mean $27 \mathrm{ppb}$ ) (Dalcero et al., 2002). In South Africa, ochratoxin reported the lowest prevalence (4\% of samples) with levels ranged between 6.4 and 17.1 ppb (mean: 9.9 ppb) (Njobeh et al., 2012). In Cameroon, Abia et al. (2013) analyzed 20 feed samples pools collected from different poultry farms and reported the ochratoxins rate of $80-90 \%$. In Argentina, Greco et al. (2014) detected ochratoxin in $90 \%$ of the poultry feed samples (median $5 \mathrm{ppb}$ ) and aflatoxins (median $2.685 \mathrm{ppb}$ ).

The EU has set a concentration limit for zearalenone in raw maize to $100 \mathrm{ppb}$ and in cereal products to $20 \mathrm{ppb}$ (Yang et al., 2020). The incidence of detectable Zearalenone is similar to that found by previous studies conducted in several regions. In Cameroon, Abia et al. (2013) analyzed 20 feed samples pools collected from different poultry farms and reported feeds contamination with zearalenone in $100 \%$ of samples, with mean concentrations 155 (range 0.7-600) ppb. In Kuwait and Egypt, zearalenone ranged from 46.4 to $67.6 \mathrm{ppb}$ in broiler feed samples collected from a poultry feed production unit (Beg et al., 2006), and $40 \mathrm{ppb}$ in $80 \%$ of the maize samples integrated in poultry feeds (Mahmoud, 1993); respectively. In Swedish, zearalenone was detected in 2 of 68 mixed feed samples, with one showed a very high level (1200 ppb) and the other was $100 \mathrm{ppb}$ (Pettersson and Kiessling, 1992). In Argentina, Greco et al. (2014) detected Zearalenone in $86 \%$ of the poultry feed samples (median $50 \mathrm{ppb}$ ).

The EU has set a maximum limit of fumonisin in raw corn $4000 \mathrm{ppb}$ (Yang et al., 2020). The high incidence of detectable fumonisin is similar to that found by previous studies conducted in several countries. In Kuwait, fumonisin ranged from 1.4 to $3.2 \mathrm{ppm}$ in broiler feed samples collected from a feed factory (Beg et al., 2006). In Nigeria, fumonisin B1 was detected in most of the samples (97\%) (Range, 37-3760 ppb; mean, 1014 ppb) (Akinmusire et al., 2019), as well as Ezekiel et al. (2012) detected fumonisins in $83 \%$ of 58 commercial poultry feed samples in Nigeria, with concentrations range, 31- 2733 ppb; and mean, 964 ppb. In South Africa, Njobeh et al. (2012) detected fumonisins in $87 \%$ of 92 compound feeds samples with concentrations range, 104-2999 ppb; and mean 903 ppb. In Cameroon, Abia et al. (2013) analyzed 20 feed samples pools collected from poultry farms and reported fumonisins in $100 \%$ of samples, with concentrations range, 16- $1930 \mathrm{ppb}$; and mean, $468 \mathrm{ppb}$. In Taiwan, Tseng and Liu (2001) detected fumonisin in few samples of imported maize at level exceeded $0.3 \mathrm{ppm}$. In Iran, Shephard, et al. (2002) detected fumonisin B1 in maize at average levels of $3.18 \mathrm{ppm}$ (range 0.68 to 7) and $0.22 \mathrm{ppm}$ (range $<0.01$ to 0.88 ) in two areas. Likewise, In the United Kingdom, maize feedstuffs were reported to frequently contain fumonisin B1 and B2 at levels up to 5 ppm (Scudamore et al., 1997). In Argentina, Greco et al. (2014) detected Fumonisins in all the samples in a range of 222-6,000 ppb (median 1,750 ppb).

The combined toxic effects of aflatoxin, ochratoxin, zearalenone, and fumonisins in feed and food might pose a veterinary and public health risk. Overall, results indicated that $86.60 \%$ of compound feed and feed ingredient samples contained two or more mycotoxins. Combined contamination with aflatoxin and ochratoxin was detected in $76.8 \%$ of the samples. In Argentina, Greco et al. (2014) found that $90 \%$ of poultry feed samples were contaminated with ochratoxin and aflatoxins. Beg et al. (2006) detected the coexistence of ochratoxin A, fumonisin, and zearalenone in poultry feed from Kuwait, although in lower concentrations than the permissible limits defined for the poultry feed. In Bangladesh, Dawlatana et al. (2002) confirmed the possibility of multiple mycotoxins contamination in poultry feed and detected five mycotoxins in one sample of maize. While in Nigeria, Akinmusire et al. (2019) reported contamination with at least four mycotoxins in 102 samples of feed and feed ingredients collected from poultry farms, as they detected fumonisin B1 in most of the samples (97\%) and 
AFB1 in $83 \%$ of feed samples. Also, Scudamore et al. (1997) detected multi-mycotoxin contamination with both aflatoxin and fumonisin in some samples of maize. Magnoli et al. (2002) reported that fumonisins had the highest incidence (97\%) followed by AFB1 (46\%) and zearalenone (18\%). Moreover, Aravind et al. (2003) analyzed a commercial broilers diet naturally contaminated with mycotoxins in India, and reported contamination with aflatoxins, ochratoxin, and zearalenone toxins, and suggested the possible synergistic toxic effect from the combination of multiple mycotoxins offered in the contaminated feed.

The presence of mycotoxins in animal products is the most critical aspect and a serious factor affecting meat quality that has a special public health concern. As presented in Table 5, aflatoxins residues were detected in all examined tissue samples that collected from the commercial broiler chickens in three provinces, Egypt with detectable levels above the recommended permissible limit for human consumption (4 ng/g) according to FDA regulations. These results came in agreement with Herzallah (2009) who documented the levels of AFB1, $\mathrm{AFB} 2$, aflatoxin $\mathrm{G} 1$ and $\mathrm{G} 2$ ranged from 1.10 to 8.32 $\mathrm{mg} / \mathrm{kg}$ and 0.15 to $6.36 \mathrm{mg} / \mathrm{kg}$ in imported and fresh meat samples. Moreover, Iqbal et al. (2014) and Markov et al. (2013) reported that AFB1 was detected in 10\% and 35\% of the collected chicken samples from Croatia and Pakistan, with maximum levels $3.0 \mathrm{mg} / \mathrm{kg}$ and $8.01 \mathrm{mg} / \mathrm{kg}$, respectively.

Collectively, mean total aflatoxin residues in the liver of all examined samples were higher than their levels in the breast and thigh muscle tissues (Table 5). Similarly, Magnoli et al. (2011) and Herzallah et al. (2014) reported aflatoxin and its metabolites residues in the different tissues of broiler chicks fed aflatoxin-contaminated diets with different concentrations and various treatments. These recorded results related to the ability of poultry to metabolize and eliminate aflatoxin from their tissues.

\section{CONCLUSION}

In this study, all broiler compound feed samples collected from feed production units were contaminated with aflatoxins and ochratoxins, while zearalenone and fumonisin were detected at $56.8 \%$ and $16.2 \%$ of samples, respectively. Moreover, $30.6 \%$ of aflatoxin-positive samples and $91 \%$ of ochratoxin-positive samples exceeded the permissible limit in compound feed. Co-contamination with two or more types of different mycotoxins was recorded in $86.6 \%$ of tested compound feed and feed ingredients and the combined contamination with aflatoxin and ochratoxin was found in $76.8 \%$ of positive samples. Aflatoxin residues that exceeded the recommended permissible limit for human consumption were detected in $100 \%$ of broiler meat and liver samples.

\section{DECLARATIONS}

\section{Competing interests}

The authors have no competing interests.

\section{Acknowledgment}

This study was carried out in Mycotoxin Research Lab and partially supported by the project titled "Mycotoxicosis, the natural potent immunosuppressive carcinogen of veterinary and public health concern scientific research sector of Cairo University.

\section{Authors' contribution}

Anwaar Mettwally El-Nabarawy designed the experiment, provided the facilities and the material needed, performed mycotoxins detection and determination, wrote and revised the manuscript. Elshaimaa Ismael contributed to mycotoxins detection and determination, designed the figures, wrote and revised the manuscript. Sawsan El Basuni collected broiler tissue samples, performed the extraction of aflatoxin residues and wrote the manuscript. Khaled Shaaban contributed to mycotoxin detection and determination. Mohamed Mohamed Ismail Batikh collected feed and broiler tissue samples

\section{REFERENCES}

Abia WA, Simo GN, Warth B, Sulyok M, Krska R, Tchana A and Moundipa PF (2013). Determination of multiple mycotoxins levels in poultry feeds from Cameroon. Japanese Journal of Veterinary Research, $61 \quad$ (Supplement): S33-S39. DOI: https://doi.org/10.14943/jjvr.61.suppl.s33.

Akinmusire OO, El-Yuguda AD, Musa JA, Oyedele OA, Sulyok M, Somorin YM and Krska R (2019). Mycotoxins in poultry feed and feed ingredients in Nigeria. Mycotoxin Research, 35(2): 149-155. DOI: https://doi.org/10.1007/s12550-018-0337-y

Aravind KL, Patil VS, Devegowda G, Umakantha B and Ganpule S P (2003). Efficacy of esterified glucomannan to counteract mycotoxicosis in naturally contaminated feed on performance and serum biochemical and hematological parameters in broilers. $\begin{array}{llrl}\text { Poultry } & \text { Science, } & \text { 82(4): }\end{array}$ https://doi.org/10.1093/ps/82.4.571

Atalla MM, Hassanein NM, El-Beih, AA and Youssef YAG (2003). Mycotoxin production in wheat grains by different Aspergilli in relation to different relative humidities and storage periods. $\begin{array}{lll}\text { Food/Nahrung, } & 47(1): & 6-10 .\end{array}$ https://doi.org/10.1002/food.200390017.

Awuor AO, Yard E, Daniel JH, Martin C, Bii C, Romoser A, Oyugi E, Elmore S, Amwayi S, Vulule J, et al. (2017). Evaluation of the efficacy, acceptability and palatability of calcium montmorillonite clay used to reduce aflatoxin B1 dietary exposure in a crossover study in Kenya. Food Additives and Contaminants - Part A 
Chemistry, Analysis, Control, Exposure and Risk Assessment, 34(1): 93-102. DOI: https://doi:10.1080/19440049.2016.1224933

Beg MU, Al-Mutairi M, Beg KR, Al-Mazeedi HM, Ali LN and Saeed T (2006). Mycotoxins in poultry feed in Kuwait. Archives of Environmental Contamination and Toxicology, 50(4): 594-602. DOI: https://doi.org/10.1007/s00244-005-2094-0.

Bryden WL (2012). Mycotoxin contamination of the feed supply chain: Implications for animal productivity and feed security. Animal Feed Science and Technology, 173(1-2): 134-158. DOI: https://doi.org/10.1016/j.anifeedsci.2011.12.014.

Chandrasekaran D (1996). Survey on the presence of T-2 Toxin and ochratoxin in feed/ingredients in Namakkal area. In Proceedings of the 20th World's Poultry Congress. WPSA (India Branch), Pune, India (Vol. 268).

Dalcero A, Magnoli C, Hallak C, Chiacchiera SM, Palacio G and Rosa CDR (2002). Detection of ochratoxin A in animal feeds and capacity to produce this mycotoxin by Aspergillus section Nigri in Argentina. Food Additives \& Contaminants, 19 (11): 1065-1072. DOI: https://doi.org/10.1080/02652030210151895

Dawlatana M, Coker RD, Nagler MJ, Wild CP, Hassan MS and Blunden, $\mathrm{G}$ (2002). The occurrence of mycotoxins in key commodities in Bangladesh: surveillance results from 1993 to 1995. Journal of Natural Toxins, 11(4): 379-386. Available at https://europepmc.org/article/med/12503882.

European Commission (EC) (2006). Commission Recommendation of 17 August 2006 on the presence of deoxynivalenol, zearalenone, ochratoxin A, T-2 and HT-2 and fumonisins in products intended for animal feeding (2006/576/EC). Official Journal of the European Union, 229: 7-9.

Elnabarawya AM, Madian K, Aly EA H and Madbouly YM (2016). The effect of mycotoxins on immune response of broilers to the live ND vaccines applied by different routes. Middle East Journal of Applied Sciences, 6 (1): 51-58. Available at: http://www.curresweb.com/mejas/mejas/2016/51-58.pdf

Elnabarawya AM, Madian K, Shaheed IH and Abd El-Ghany WA. (2020). Evaluation of different antimycotoxins for controlling mycotoxicosis in broiler chickens. The Journal of World's Poultry Research, In press.

Ezekiel CN, Bandyopadhyay R, Sulyok M, Warth B and Krska, R (2012). Fungal and bacterial metabolites in commercial poultry feed from Nigeria. Food Additives \& Contaminants: Part A, 29 (8): 1288-1299. DOI: https://doi.org/10.1080/19440049.2012.688878

FDA (2000). Guidance for industry: action levels for poisonous or deleterious substances in human food and animal feed. United States Food and Drug Administration, Washington, DC. Available at: https://www.fda.gov/regulatory-information/search-fdaguidance-documents/guidance-industry-action-levels-poisonous-ordeleterious-substances-human-food-and-animal-feed

FDA (2001). Guidance for industry: fumonisin levels in human foods and animal feeds. United States Food and Drug Administration, Washington DC. pp. 56688-56689. Available at: https://www.fda.gov/regulatory-information/search-fda-guidancedocuments/guidance-industry-fumonisin-levels-human-foods-andanimal-feeds

FDA (2010). Guidance for industry and FDA: advisory levels for deoxynivalenol (DON) in finished wheat products for human consumption and grains and grain by-products used for animal feed. United States Food and Drug Administration: Silver Spring, MD, USA, 2010. Available at: https://www.fda.gov/regulatoryinformation/search-fda-guidance-documents/guidance-industryand-fda-advisory-levels-deoxynivalenol-don-finished-wheatproducts-human

Fernández A, Hernández M, Verde M T and Sanz M (2000). Effect of aflatoxin on performance, hematology, and clinical immunology in lambs. The Canadian Journal of Veterinary Research, 64(1):53-8.
PMID: $\quad 10680657 . \quad$ Available at: https://www.ncbi.nlm.nih.gov/pmc/articles/PMC1189581/

Greco MV, Franchi ML, Rico Golba SL, Pardo AG and Pose GN (2014). Mycotoxins and mycotoxigenic fungi in poultry feed for foodproducing animals. The Scientific World Journal, 2014: 968215. DOI: https://doi.org/10.1155/2014/968215.

Herzallah SM (2009). Determination of aflatoxins in eggs, milk, meat and meat products using HPLC fluorescent and UV detectors. Food Chemistry, $\quad 114 \quad$ (3): $1141-1146 . \quad$ DOI: https://doi.org/10.1016/j.foodchem.2008.10.077.

Huff WE, and Doerr JA (1981). Synergism between aflatoxin and ochratoxin A in broiler chickens. Poultry Science, 60 (3): 550-555. DOI: https://doi.org/10.3382/ps.0600550

Iqbal SZ, Nisar S, Asi MR and Jinap S (2014). Natural incidence of aflatoxins, ochratoxin A and zearalenone in chicken meat and eggs. Food Control, 43: 98-103. DOI: https://doi.org/10.1016/j.foodcont.2014.02.046.

Kana JR, Gnonlonfin BGJ, Harvey J, Wainaina J, Wanjuki I, Skilton RA and Teguia A (2013). Assessment of aflatoxin contamination of maize, peanut meal and poultry feed mixtures from different agroecological zones in Cameroon. Toxins, 5 (5): 884-894. DOI: https://doi.org/10.3390/toxins5050884.

Kensler TW, Qian GS, Chen JG, and Groopman JD (2003). Translational strategies for cancer prevention in liver. Nature Reviews Cancer, 3: 321-329. DOI: https://doi.org/10.1038/nrc1076

Klich, MA (2007). Environmental and developmental factors influencing by Aspergillus flavus and Aspergillus parasiticus. Mycoscience, 48(2): 71-80. DOI: https://doi.org/10.1007/S10267-006-0336-2

Kovalsky P, Kos G, Nährer K, Schwab C, Jenkins T, Schatzmayr G and Krska R (2016). Co-occurrence of regulated, masked and emerging mycotoxins and secondary metabolites in finished feed and maize-An extensive survey. Toxins, 8 (12): 363 . DOI: https://doi.org/10.3390/toxins8120363.

Magnoli C, Chiacchiera SM, Miazzo R, Palacio G, Angeletti A, Hallak C and Dalcero A (2002). The mycoflora and toxicity of feedstuffs from a production plant in Cordoba, Argentina. Mycotoxin Research, 18 (1): 7-22. DOI: https://doi.org/10.1007/BF02946135

Mahmoud AL (1993). Toxigenic fungi and mycotoxin content in poultry feedstuff ingredients. Journal of Basic Microbiology, 33(2): 101104 DOI: https://doi.org/10.1002/jobm.3620330205

Maiyoh GK, and Tuei VC. (2019). Rising cancer incidence and role of the evolving diet in Kenya. Nutrition and Cancer, 71 (4): 531-546. DOI: https://doi.org/10.1080/01635581.2018.1542010.

Malir F, Ostry V, Pfohl-Leszkowicz A, Malir J and Toman J (2016). Ochratoxin A: 50 Years of Research. Toxins, 8 (7): 191. DOI: https://doi:10.3390/toxins8070191

Markov K, Pleadin J, Bevardi M, Vahčić N, Sokolić-Mihalak D and Frece J (2013). Natural occurrence of aflatoxin B1, ochratoxin A and citrinin in Croatian fermented meat products. Food Control, 34 (2): 312-317. DOI: https://doi.org/10.1016/j.foodcont.2013.05.002.

Mohd-Redzwan S, Jamaluddin R, Abd-Mutalib MS and Ahmad Z (2013). A mini review on aflatoxin exposure in Malaysia: past, present and future. Frontiers in Microbiology, 4: 334. DOI: https://doi:10.3389/fmicb.2013.00334

Natour RM, Al-Awadi A, Illian M and Salman AJ (1983). Aflatoxin and aflatoxigenic fungi in poultry feed in Kuwait. In 1. Scientific Meeting, Arab Society for Plant Protection, Amman (Jordan), 22-25 Nov 1982.

Nizamlýolu F. and H. Oguz (2003). Occurrence of aflatoxins in layer feed and corn samples in Konya province, Turkey. Food Additives and Contaminants, 20(7): 654-658 DOI: https://doi.org/10.1080/02652030303842.

Njobeh PB, Dutton MF, Åberg AT and Haggblom P (2012). Estimation of multi-mycotoxin contamination in South African compound 
El-Nabarawy et al., 2020

feeds. $\quad$ Toxins, 4 (10): $\quad$ 836-848. $\quad$ DOI: https://doi.org/10.3390/toxins4100836

Pappas AC, Tsiplakou E, Georgiadou M, Anagnostopoulos C, Markoglou AN, Liapis K and Zervas G (2014). Bentonite binders in the presence of mycotoxins: Results of in vitro preliminary tests and an in vivo broiler trial. Applied Clay Science, 99: 48-53. DOI: https://doi.org/10.1016/j.clay.2014.06.009.

Park DL, and Troxell TC (2002). US Perspective on Mycotoxin Regulatory Issues. In: Mycotoxins and Food Safety, pp. 277-285. Springer, Boston, MA. Available at: https://link.springer.com/chapter/10.1007/978-1-4615-0629-4_29.

Pettersson H, and Kiessling KH. (1992). Mycotoxins in Swedish grains and mixed feeds. Journal of Environmental Pathology, Toxicology and Oncology: Official Organ of the International Society for Environmental Toxicology and Cancer, 11 (2): 41-43. Available at: https://europepmc.org/article/med/1573563.

Scudamore KA, Hetmanski MT, Chan HK and Collins S (1997). Occurrence of mycotoxins in raw ingredients used for animal feeding stuffs in the United Kingdom in 1992. Food Additives \& $\begin{array}{llll}\text { Contaminants, } & 14 & (2): & 157-173 .\end{array}$ https://doi.org/10.1080/02652039709374511.

Shephard GS, Marasas WFO, Yazdanpanah H, Rahimian H, Safavi N, Zarghi A and Rasekh HR (2002). Fumonisin B 1 in maize harvested in Iran during 1999. Food Additives \& Contaminants, 19 (7): 676679. DOI: https://doi.org/10.1080/02652030210126541

Thirumala-Devi K, Mayo MA, Reddy G and Reddy DVR (2002). Occurrence of aflatoxins and ochratoxin A in Indian poultry feeds. Journal of Food Protection, 65 (8): 1338-1340. DOI: https://doi.org/10.4315/0362-028X-65.8.1338.

Tseng TC, and Liu CY (2001). Occurrence of fumonisin B1 in maize imported into Taiwan. International Journal of Food Microbiology, 65 (1-2): 23-26. DOI: https://doi.org/10.1016/S01681605(00)00507-9. van Egmond HP and Jonker MA (2004a). Worldwide Regulations on Aflatoxins-The Situation in 2002. Journal of Toxicology: Toxin Reviews, 23 (2-3): 273-293. DOI: https://doi.org/10.1081/TXR200027844

van Egmond HP and Jonker M (2004b). Worldwide regulations for mycotoxins in food and feed in 2003: Food and Agriculture Organization of the United Nations. Available at: http://www.fao.org/3/y5499e/y5499e00.htm

VICAM (1999). AflaTest WB SR Instruction Manual. Watertown, MA, p. 2472. Available at: http://www.biotic.com.tw/index.files/GNMC9508-5\%20(AflaTest).pdf

VICAM (2008). OchraTest and OchraTest WB Instruction Manual. Watertown, MA, p. 25. Available at: http://www.weber.hu/Downloads/VicamManuals/G1033.pdf

VICAM (2013). ZearalaTest Instruction Manual (for Fluorometric use). Watertown, MA. Available at: http://vicam.com/instructionalmanuals/ZearalaTest-Fluorometer-Instruction-Manual

VICAM (2015). FumoniTest Fluorometer Instruction Manual. Watertown, MA. Available at: http://www.weber.hu/Downloads/VicamManuals/G1060.pdf

Wild CP and Gong YY (2010). Mycotoxins and human disease: a largely ignored global health issue. Carcinogenesis, 31 (1): 71-82. DOI: https://doi.org/10.1093/carcin/bgp264

Williams JH, Phillips TD, Jolly CM, and Aggarwal D (2004). Human aflatoxicosis in developing countries: a review of toxicology, exposure, potential health consequences, and interventions. The American journal of clinical nutrition, 80 (50): 1106-1122. DOI: https://doi.org/10.1093/ajcn/80.5.1106

Yang C, Song G, Lim W (2020). Effects of mycotoxin-contaminated feed on farm animals. Journal of Hazardous Materials, 389: 122087. DOI: https://doi.org/10.1016/j.jhazmat.2020.122087 